\title{
Penetapan Status Tersangka Dan Terdakwa Calon Kepala Daerah Dan Implikasi Yuridisnya Dalam Pemilihan Kepala Daerah (Kajian Yuridis Normatif)
}

\author{
Imam Ropii \\ Dosen Fakultas Hukum Universitas Wisnuwardhana Malang. \\ E-mail:mamiku01667@gmail.com
}

\begin{abstract}
Political contestation in the election of regional heads simultaneously in the third stage of 2017 became popular in particular the election of regional heads in Jakarta Special Capital Region (DKI). The popularity of DKI Regional Head election is because one of the candidates of the regional head (petahana candidate) is currently a suspect status and has even increased to be the defendant for allegedly doing the act of defamation of religion. The juridical of the candidate for the head of a suspect or defendant has no effect on the nomination process in the election. Couple of candidates with such status will continue to follow the election stage to complete. If in the Pilkada the suspect's partner or the defendant wins, the convicted person will be dismissed and subsequently replaced as stipulated in the legislation.
\end{abstract}

Keywords: status of candidate for regional head, implication, election of regional head

\section{A. PENDAHULUAN.}

Kontestasi pemilihan kepala daerah serentak 2017 menjadi magnit politik tersendiri dimana media masa telah menyuguhi publik dengan tontonan politik dan hukum yang menarik, yaitu Basuki Tjahaja Purnama atau Ahok, sang calon petahana Gubernur DKI Jakarta ditetapkan sebagai tersangka dan bahkan sekarang sudah menjadi terdakwa oleh Bareskrim Polri atas dugaan tindak pidana menistakan agama Islam. Peristiwa tersebut benar-benar menyita perhatian publik yang luar biasa.
Sebagai bentuk reaksi atas dugaan tindak pidana tersebut, maka pada tanggal 2 Nopember 2016 (dikenal juga dengan istilah 211) terjadi demonstrasi besar-besaran di Jakarta yang diikuti lebih kurang 7 juta orang lebih yang berasal dari berbagai daerah di Indonesia dengan mengatasnamakan solidaritas pembela Islam. Berdasarkan peristiwa tersebut, warga DKI Jakarta dalam pemilihan kepala daerah dihadapkan pada pilihan pasangan calon kepala daerah yang salah satunya sedang berstatus tersangka dan bahkan meningkat sebagai terdakwa. 
Di media masa baik cetak maupun elektronik banyak kita temukan pertanyaan para netizen (pembaca/pengguna sosial media) terhadap kelanjutan pencalonan dan pemilihan dalam Pilkada DKI terhadap Basuki Tjahaya Purnama (Ahok) sebagai pasangan calon kepala daerah/wakil kepala daerah bersama Jarot Saiful Hidayat. Pertanyaan publik yang demikian tentunya wajar dan syah-syah saja sebagai bagian dari proses demokratisasi Pilkada. Kebetulan pada Pilkada DKI inilah seorang calon kepala daerah menyandang status sebagai tersangka/terdakwa sehingga menambah hiruk pikuk penyelenggaraan Pilkada serentak menjadi lebih ramai.

Pemilihan kepala daerah serentak tahap ke tiga (2017) sejak pertama kali diselenggarakan pada tahun 2015 yang lalu sebagai implementasi dari salah satu dari prinsip demokrasi, yakni dilakukannya pemilihan pejabat publik (kepala daerah) secara periodik (lima tahun sekali). Pilkada yang demokratis untuk menghasilkan pemimpin daerah yaitu pasangan kepala daerah dan wakilnya yang absah serta berintegritas merupakan cita-cita dan harapan kita semua dalam berdemokrasi. Karena itu, arti penting demokrasi dalam Pilkada tidak hanya sekedar seremonial demokrasi untuk memilih pasangan calon kepala daerah semata melainkan juga untk menjalankan proses demokrasi secara baik dan berintegritas.

Merujuk teori kontrak sosial yang diajarkan J.J. Rosseau, maka Pilkada DKI hendaknya dilaksanakan dengan cara yang mendekati pada tercapainya kehendak (pilihan mayoritas) masyarakat. Calon pemimpin dan penyelenggara pemerintahan yang terpilih harus memiliki integritas dan kapabilitas yang sesuai dengan harapan. Karena itu pengetahuan, integritas serta kecerdasan pemilih dalam memilih pemimpin dalam Pilkada menjadi faktor sangat penting. Berintegritas dimaksudkan memiliki sikap yang terpuji, mampu menjadi tauladan, dapat dipercaya, adil/bijaksana, dan lain sebagainya. Kapabilitas dimaksudkan mereka yang terpilih memiliki kemampuan dan kesanggupan untuk memimpin dan menjalankan pemerintahan daerah secara amanah, profesional berdasarkan hukum. Persoalan yang kemudian muncul ialah ketika seseorang tengah berstatus calon kepala daerah dalam kontestasi Pilkada namun ia juga sedang berstatus sebagai tersangka atau terdakwa, apa implikasi yuridisnya?

Pembahasan dalam tulisan ini mengkaji ketentuan yang mengatur bagaimana penetapan status tersangka/terdakwa terhadap pasangan calon kepala daerah dalam proses Pilkada tersebut. Secara berurut tulisan ini akan mengupas secara normatif tentang ketentuan calon dan pencalonan kepala daerah, prosedur dan syarat pencalonan kepala daerah dalam Pilkada, akibat hukum penetapan calon kepala daerah, hak dan kewajiban calon kepala daerah, dan implikasi hukum calon kepala daerah terpilih yang berstatus tersangka, terdakwa dan terpidana.

\section{B. PEMBAHASAN}

\section{Ketentuan Calon dan Pencalonan Kepala Daerah dalam Pilkada}

Setiap pasangan calon (baik jalur independen/non partai maupun calon yang diusung lewat jalur partai) yang ingin mendaftarkan diri sebagai pasangan calon kepala daerah dan calon wakil kepala daerah dalam Pemilihan Kepala Daerah (Pilkada) harus mengikuti dan memenuhi ketentuan yang telah diatur di dalam UU Pemilihan kepala daerah. Ketentuan yang mengatur tentang calon dan pencalonan kepala daerah dalam Pilkada diatur dalam Pasal 7 UU No. 
10 Tahun 2016 yang merupakan perubahan kedua atas UU No. 1 Tahun 2015 tentang Penetapan Peraturan Pemerintah Pengganti UU Nomor 1 Tahun 2014 Tentang Pemilihan Gubernur, Bupati, Dan Walikota Menjadi Undang-undang.

Pasal 7 ayat (1) UU No. 10 Tahun 2016 mengatur tentang hak setiap warga negara memperoleh kesempatan yang sama untuk mencalonkan diri dan dicalonkan sebagai Calon Gubernur (Cagub) dan Calon Wakil Gubernur (Cawagub) , Calon Bupati (Cabup) dan Calon Wakil Bupati (Cawabup), serta Calon Walikota (Cawakot) dan Calon Wakil Walikota (Cawawakot). Kemudian dalam ayat (2) diatur tentang syarat calon kepala daerah dan wakilnya yang disebutkan pada ayat (1) harus memenuhi persyaratan sebagaimana dimaksud dalam Pasal 7 ayat (2) tersebut.

Dalam undang-undang Pilkada tersebut diatur ketentuan calon kepala daerah pada dan pencalonan (syarat mencalonkan) kepala daerah. UU No. 2016 Pasal 40 (1) Parpol atau gabungan Parpol dapat mendaftarkan pasangan calon jika telah memenuhi persyaratan perolehan paling sedikit $20 \%$ dari jumlah kursi DPRD atau 25\% dari akumulasi perolehan suara sah dalam pemilihan umum anggota DPRD di daerah yang bersangkutan. Selanjutnya dalam ayat (2) dinyatakan, Dalam hal Parpol atau gabungan Parpol dalam mengusulkan pasangan calon menggunakan ketentuan memperoleh paling sedikit 20\% dari jumlah kursi DPRD sebagaimana dimaksud pada ayat (1), jika hasil bagi jumlah kursi DPRD menghasilkan angka pecahan maka perolehan dari jumlah kursi dihitung dengan pembulatan ke atas. Kemudian pada ayat (3) Dalam hal Parpol atau gabungan Parpol mengusulkan pasangan calon menggunakan ketentuan memperoleh paling sedikit $25 \%$ dari akumulasi perolehan suara sah sebagaimana dimaksud pada ayat (1), ketentuan itu hanya berlaku untuk Parpol yang memperoleh kursi di DPRD. Selanjutnya di ayat (4) Parpol atau gabungan Parpol sebagaimana dimaksud pada ayat (1) hanya dapat mengusulkan 1 (satu) pasangan calon, dan calon tersebut tidak dapat diusulkan lagi oleh Parpol atau gabungan Parpol lainnya.

Selanjutnya ketentuan UU No. 2016 Pasal 41 (1) mengatur tentang calon perseoranagan. Calon perseorangan yang mendaftarkan diri sebagai Calon Gubernur (Cagub) dan Calon Wakil Gubernur (Cawagub) jika memenuhi syarat dukungan jumlah penduduk yang mempunyai hak pilih dan termuat dalam daftar pemilih tetap pada pemilihan umum atau Pemilihan sebelumnya yang paling akhir di daerah bersangkutan, dengan ketentuan:

a. Jumlah penduduk sampai dengan 2.000.000 jiwa didukung paling sedikit $10 \%$;

b. Jumlah penduduk lebih dari 2 - 6 juta jiwa didukung paling sedikit $8,5 \%$;

c. Jumlah penduduk lebih dari $6-12$ juta jiwa didukung paling sedikit $7,5 \%$;

d. Jumlah penduduk lebih dari 12.000.000 jiwa didukung paling sedikit $6,5 \%$;

e. Jumlah dukungan tersebut di atas tersebar di lebih dari 50\% jumlah kabupaten/kota di Provinsi dimaksud.

Calon perseorangan yang mendaftarkan diri sebagai Calon Bupati/Calon Wakil Bupati serta Calon Walikota/Calon Wakil Walikota jika memenuhi syarat dukungan jumlah penduduk yang mempunyai hak pilih dan termuat dalam daftar pemilih tetap (DPT) di daerah bersangkutan pada pemilihan umum atau Pemilihan sebelumnya yang paling akhir di daerah bersangkutan dengan ketentuan:

a. Jumlah penduduk sampai dengan 250.000 jiwa dukungan paling sedikit $10 \%$;

b. Jumlah penduduk lebih dari 250.000 - 
500.000 dukungan paling sedikit $8,5 \%$;

c. Jumlah penduduk lebih dari 500.000-1 juta dukungan paling sedikit 7,5\%,

d. Jumlah penduduk lebih dari 1 juta jiwa harus didukung paling sedikit $6,5 \%$;

e. Jumlah dukungan tersebut di atas harus tersebar di lebih dari 50\% jumlah kecamatan di kabupaten/kota dimaksud.

Pernyataan dukungan terhadap calon perseorangan oleh penduduk dibuat dalam bentuk surat dukungan yang disertai dengan fotokopi Kartu Tanda Penduduk Elektronik atau surat keterangan yang diterbitkan oleh dinas kependudukan dan catatan sipil (Dispendukcapil) yang menerangkan bahwa penduduk tersebut berdomisili di wilayah administratif yang sedang menyelenggarakan Pemilihan paling singkat 1 (satu) tahun dan tercantum dalam DPT Pemilu sebelumnya di provinsi atau kabupaten/kota dimaksud. Dukungan hanya diberikan kepada 1 (satu) pasangan calon perseorangan".

Bagaimana format ketentuan pernyataan dukungan terhadap calon perseorangan? Menurut Peraturan KPU No. 9/2015 tentang Pencalonan Pemilihan Kepala Daerah diatur sebagai berikut :

PKPU No. 9/2015 Pasal 14 :

(1) Dokumen dukungan sebagaimana dimaksud dalam Pasal 13 ayat (1) berupa surat pernyataan dukungan, dengan dilampiri fotokopi identitas kependudukan dan rekapitulasi jumlah dukungan.

(2) Surat pernyataan dukungan sebagaimana dimaksud pada ayat (1) dapat menggunakan formulir Model B.1-KWK Perseorangan.

(3) Dalam hal Pasangan Calon perseorangan telah menghimpun surat pernyataan dukungan secara perseorangan atau kolektif, tapi tidak menggunakan formulir Model
B.1-KWK Perseorangan, Pasangan Calon perseorangan wajib menyusun daftar nama pendukung kedalam formulir Model B.1-KWK Perseorangan, dilampiri surat pernyataan dukungan yang telah dihimpun yang berisi data nomor induk kependudukan, alamat, Rukun Tetangga(RT)/Rukun Warga (RW), desa atau sebutan lain/kelurahan, kecamatan,kabupaten/kota, tempat dan tanggal lahir/umur, jenis kelamin, dan status perkawinan.

Ketentuan tentang calon kepala darah dan wakil kepala daerah tersebut wajib dipenuhi sebelum pasangan tersebut mencalonkan diri menjadi calon kepala daerah, sedangkan ketentuan tentang pencalonan kepala daerah/wakil kepala daerah harus dipenuhi saat Parpol/gabungan Parpol atau perseorangan mendaftarkan diri sebagai pasangan calon kepala daerah.

\section{Prosedur dan Syarat Pencalonan Kepala Daerah dalam Pilkada}

Untuk dapat mencalonkan kepala daerah dan wakilnya dalam Pilkada telah diatur prosedur pencalonan yang harus dilalui sebelum ditetapkan menjadi calon kepala daerah oleh KPUDsetempat. Prosedur pencalonan kepala daerah diatur dalam Pasal 42-44 UU 10/2016.

Pasal 42 UU No. 10/2016 :

(1) Pasangan Cagub dan Cawagub didaftarkan ke KPU Provinsi oleh Parpol atau gabungan Parpol, atau perseorangan.

(2) Pasangan Cabup Cawabup serta pasangan Cawali dan Cawawali didaftarkan ke KPU Kabupaten/Kota oleh Parpol, gabungan Parpol, atau perseorangan.

(3) Cagub dan Cawagub, Cabup Cawabup, dan Cawali dan Cawawali harus memenuhi persyaratan sebagaimana dimaksud dalam Pasal 7.

(4) Pendaftaran pasangan Cagub dan Cawagub oleh Parpol 
ditandatangani oleh ketua Parpol dan sekretaris Parpol tingkat Provinsi disertai Surat Keputusan Pengurus Parpol tingkat Pusat tentang Persetujuan atas calon yang diusulkan oleh Pengurus Parpol tingkat Provinsi.

(4a) Dalam hal pendaftaran pasangan calon tidak dilaksanakan oleh pimpinan Parpol tingkat Provinsi, pendaftaran pasangan calon yang telah disetujui Parpol tingkat Pusat, dapat dilaksanakan oleh pimpinan Parpol tingkat Pusat.

(5) Pendaftaran pasangan Cabup Cawabup, dan Cawali dan Cawawali oleh Parpol ditandatangani oleh ketua Parpol dan sekretaris Parpol tingkat Kabupaten/Kota disertai Surat Keputusan Pengurus Parpol tingkat Pusat tentang Persetujuan atas calon yang diusulkan oleh Pengurus Parpol Kabupaten/Kota.

(5a) Dalam hal pendaftaran pasangan calon Cabup Cawabup, dan Cawali dan Cawawali tidak dilaksanakan oleh pimpinan Parpol tingkat Kabupaten/Kota, pendaftaran pasangan calon yang telah disetujui Partai Politik tingkat Pusat, dapat dilaksanakan oleh pimpinan Partai Politik tingkat Pusat.

(6) Pendaftaran pasangan Cagun dan Cawagub, Cabup Cawabup, dan Cawali dan Cawawali oleh gabungan Parpol ditandatangani oleh para ketua Parpol dan para sekretaris Parpol di tingkat Provinsi atau para ketua Parpol dan para sekretaris Parpol di tingkat Kabupaten/Kota disertai Surat Keputusan masing-masing Pengurus Parpol tingkat Pusat tentang Persetujuan atas calon yang diusulkan oleh Pengurus Parpol tingkat Provinsi dan/atau Pengurus Parpol tingkat Kabupaten/Kota.

Berdasarkan ketentuan Pasal 42 UU No. 10/2016 tersebut jelas, bahwa bagi pengurus Parpol di daerah tidak ada pilihan lain atau harus menuruti calon kepala daerah yang telah disetujui oleh pimpinan pusat Parpol penggusung untuk didaftarkan ke KPUD sebagai pasangan calon dalam ajang Pilkada. Ketentuan Pasal 42 tersebut telah mengukuhkan "hegemoni" dan mutlaknya kekuasaan Pimpinan pusat Parpol dalam penentuan calon kepala daerah. Sebab jika ada pembangkangan/ penolakan/pembelotan pengurus Parpol di daerah pemilihan yang tidak menjalankan putusan pimpinan pusat Parpol, UU Pilkada memberi hak untuk mengambil alih/mendaftarkan secara langsung terhadap pasangan calon yang telah disetujui pusat tanpa konsultasi pengurus di daerah jika tidak melaksanakan pendaftaran sesuai dengan amanat pusat.

Ketentuan dalam Pasal 42 tersebut juga mengukuhkan dominasi pengurus Parpol pusat dalam ajang pemilihan kepala daerah khususnya terhadap pasangan calon yang diusung. Karena itu mengutanya gagasan dan juga gugatan demokratisasi terhadap Parpol oleh pengurus Parpol di daerah masih sangat jauh dari harapan berdasarkan regulasi Pilkada tersebut.

Kemudian, apa akibat/dampak hukum terhadap Parpol atau gabungan Parpol yang telah mendaftarkan pasangan calon kepala daerah kepada KPUD? UU Pilkada secara tegas melarang Parpol atau gabungan Parpol untuk menarik calon yang telah didaftarkan atau mengundurkan diri sejak pasangan calonnya tersebut mendaftarkan diri. Terhadap calon perseorangan yang mengundurkan diri, UU Pilkada mengganjar dengan ancaman hukuman administratif yang cukup berat, yakni berupa denda sebesar Rp. 20.000.000.000 (dua puluh milyar rupiah) untuk calon gubernur dan sebesar Rp. 10.000.000.000 (sepuluh milyar rupiah ) untuk calon bupati/walikota (Pasal 43 UU No. 10/2016). 
Masa pendaftaran pasangan calon kepala daerah selama 3 hari sejak pengumuman pendaftaran. Pendaftaran harus dilengkapi dengan dokumen persyaratan yang telah ditentukan sebagaimana ditentukan dalam UU Pilkada antara lain : surat pernyataan yang dibuat pasangan calon, surat keterangan sehat dan bebas narkoba, surat tanda terima laporan kekayaan calon, dan juga foto kopi ijasah dan lain-lain (Pasal 44 UU No. 1/2015 dan Pasal 45 UU No. 10/2016). Ketentuan tersebut juga berlaku bagi pasangan calon perseorangan dengan ditambah beberapa syarat khusus bagi pasangan calon perseorangan (Pasal 46 UU No. 1/2015).

Untuk mencegah terjadinya pemberian imbalan politik kepada Parpol terhadap pasangan calon kepala daerah untuk mendapatkan rekomendasi/persetujuan pencalonan, UU Pilkada telah melarang bagi Parpol untuk menerima imbalan atau memungut dalam bentuk apapun dalam proses pencalonan. Imbalan atau pungutan untuk mendapatkan rekomendasi dari Parpol yang sering disebut dengan "uang mahar Parpol". Meskipun hal tersebut telah diatur dalam bentuk UU, rasanya sangat sulit untuk dihilang atau dihindari hal tersebut karena budaya politik Parpol yang transparan dan demokratis masih belum sepenuhnya terbentuk sehingga sangat mungkin akan terjadi permintaan imbalan/mahar politik secara tersembunyi/diam-diam oleh pengurus Parpol sehingga tetap menjadikan Pilkada sebagai kontestasi politik publik yang berbayar mahal.

Dalam tataran praktek, terdapat beberapa pengganti istilah "imbalan" yang sering dikemukakan oleh media publik dengan istilah "mahar politik" atau "biaya operasional politik" atau juga "ongkos politik" dan lain-lain yang substansinya tidak berbeda (sama) dengan konsep imbalan tadi. Ancaman sanksi politik dan denda administrasi atas pelanggaran ketentuan Pilkada yaitu berupa larangan mencalonkan pasangan dalam Pilkada pada tahun berikutnya di tempat yang sama dan denda sebesar sepuluh kali lipat sesungguhnya sudah cukup maju dibanding dengan aturan sebelumnya meskipun efektifitas ketentuan tersebut sangat sulit untuk membendung terjadinya pemungutan dengan sebagai "mahar politik", "ongkos politik" bagi pasangan calon yang diusulkan oleh Parpol yang bersangkutan. Untuk lebih lengkapnya landasan penjelasan tersebut, berikut dikutip ketentuan Pasal 47 UU No. 1/2015 :

(1) Partai Politik atau gabungan Partai Politik dilarang menerima imbalan dalam bentuk apapun pada proses pencalonan Gubernur dan Wakil Gubernur, Bupati dan Wakil Bupati, serta Walikota dan Wakil Walikota.

(2) Dalam hal Partai Politik atau gabungan Partai Politik terbukti menerima imbalan sebagaimana dimaksud pada ayat (1), Partai Politik atau gabungan Partai Politik yang bersangkutan dilarang mengajukan calon pada periode berikutnya di daerah yang sama.

(3) Partai Politik atau gabungan Partai Politik yang menerima imbalan sebagaimana dimaksud pada ayat (2) harus dibuktikan dengan putusan pengadilan yang telah memperoleh kekuatan hukum tetap.

(4) Setiap orang atau lembaga dilarang memberi imbalan kepada Partai Politik atau gabungan Partai Politik dalam bentuk apapun dalam proses pencalonan Gubernur dan Wakil Gubernur, Bupati dan Wakil Bupati, serta Walikota dan Wakil Walikota.

(5) Dalam hal putusan pengadilan yang telah memperoleh kekuatan hukum tetap menyatakan setiap orang atau lembaga terbukti memberi imbalan pada proses pencalonan Gubernur dan Wakil Gubernur, Bupati dan Wakil Bupati, serta Walikota dan Wakil Walikota maka penetapan sebagai calon, pasangan calon 
terpilih, atau sebagai Gubernur, Wakil Gubernur, Bupati, Wakil Bupati, Walikota atau Wakil Walikota dibatalkan.

(6) Setiap partai politik atau gabungan partai politik yang terbukti menerima imbalan sebagaimana dimaksud pada ayat (1), dikenakan denda sebesar 10 (sepuluh) kali lipat dari nilai imbalan yang diterima.

\section{Akibat Hukum terhadap Penetapan Pasangan Calon Kepala Daerah dan Parpol Penggusung}

Apa akibat hukum terhadap pasangan calon (Paslon) yang diusulkan dan Parpol penggusung setelah pasangan calon yang direkomendasi ditetapkan sebagai Paslon kepala daerah dan wakil kepala daerah? Untuk mencegah terjadinya "sabotase politik" atau sengaja untuk menciptakan kegaduhan politik dalam Pilkada atau untuk menghambat proses Pilkada, UU Pilkada telah mengantisipasinya dengan memberikan sanksi bagi keduanya. Setelah penetapan pasangan calon kepala daerah oleh KPUD, jika Paslon atau Parpol/gabungan Parpol menarik Paslonnya dan juga calon perseorangan atau Paslon yang mengundurkan diri, UU Pilkada memberi ancaman sanksi yang keras dan tegas dikarenakan hal tersebut dapat mengganggu proses demokrasi di daerah. Akibat hukum atas pelanggaran terhadap larangan penarikan oleh Parpol atau gabungan Parpol atau pengunduran diri oleh Paslon akan mendapat sanksi baik pasangan calon maupun Parpol penggusung diperlukan untuk mencegah terjadinya peserta Pilkada untuk bermain-main atau memainkan proses kontestasi demokrasi tersebut.

Ancaman sanksi sebagai akibat dari pelanggaran pasca penetapan pasangan calon terhadap Parpol pengusung dan juga Paslon yang bersangkutan secara jelas diatur pada Pasal 53 UU No. 1/2015 sebagaimana diubah yang kedua dengan UU No. 10/2016. Berikut dikutip ketentuan yang mengatur akibat hukum pasca penetapan calon kepala daerah yang telah ditetapkan:

\section{Pasal 53 Undang-undang Nomor 1 Tahun 2015:}

(1) Partai Politik atau gabungan Partai Politik dilarang menarik calonnya dan/atau calonnya dilarang mengundurkan diri terhitung sejak ditetapkan sebagai calon oleh KPU Provinsi dan KPU Kabupaten/Kota.

(2) Dalam hal Partai Politik dan gabungan Partai Politik menarik calonnya dan/atau calonnya mengundurkan diri sebagaimana dimaksud pada ayat (1), Partai Politik atau gabungan Partai Politik yang mencalonkan tidak dapat mengusulkan calon pengganti.

(3) Calon perseorangan dilarang mengundurkan diri terhitung sejak ditetapkan sebagai calon oleh KPU Provinsi dan KPU Kabupaten/Kota.

(4) Apabila calon perseorangan mengundurkan diri dari Calon Gubernur setelah ditetapkan oleh KPU Provinsi atau Calon Bupati dan Calon Walikota setelah ditetapkan oleh KPU Kabupaten/Kota, calon dikenai sanksi administratif berupa denda sebesar Rp20.000.000.000,00 (dua puluh miliar rupiah) untuk Calon Gubernur dan Rp10.000.000.000,00 (sepuluh miliar rupiah) untuk Calon Bupati dan Calon Walikota.

Sebagai seorang calon kepala daerah yang telah ditetapkan oleh KPUD, maka secara otomatis saat itu melekat pada dirinya hak dan kewajiban sebagai calon kepala daerah. Hak dan kewajiban tersebut telah diatur dalam Pasal 63, 64, 67, 68, 70, 72 dan 73 Undang-undang Nomor 1 Tahun 2015 tentang Penetapan Perppu Nomor 1 Tahun 2014 tentang Pemilihan Gubernur, Bupati, dan Walikota Menjadi Undang-undang sebagaimana diubah 
yang kedua dengan Undang-undang Nomor 10 Tahun 2016 tentang Perubahan Kedua Atas Undang-Undang Nomor 1 Tahun 2015, sebagai berikut:

Pasal 63 Undang-undang Nomor 10 Tahun 2016 :

(1) Kampanye dilaksanakan sebagai wujud dari pendidikan politik masyarakat yang dilaksanakan secara bertanggung jawab.

(2) Kampanye sebagaimana dimaksud pada ayat (1) dilaksanakan oleh KPU Provinsi untuk Pemilihan Gubernur dan KPU Kabupaten/Kota untuk Pemilihan Bupati dan Pemilihan Walikota.

(3) Jadwal pelaksanaan Kampanye ditetapkan oleh KPU Provinsi untuk Pemilihan Gubernur dan KPU Kabupaten/Kota untuk Pemilihan Bupati dan Pemilihan Walikota dengan memperhatikan usul dari calon.

(4) Ketentuan lebih lanjut mengenai tata cara pelaksanaan Kampanye sebagaimana dimaksud pada ayat (2) diatur dengan Peraturan KPU.

\section{Pasal 64 Undang-undang Nomor 1 Tahun 2016}

(1) Pasangan calon wajib menyampaikan visi dan misi yang disusun berdasarkan Rencana Pembangunan Jangka Panjang Daerah Provinsi atau Rencana Pembangunan Jangka Panjang Daerah Kabupaten/Kota secara lisan maupun tertulis kepada masyarakat.

(2) Pasangan calon berhak untuk mendapatkan informasi atau data dari Pemerintah Daerah sesuai dengan ketentuan peraturan perundang-undangan.

(3) Penyampaian materi Kampanye dilakukan dengan cara yang sopan, tertib, dan bersifat edukatif.

\section{Pasal 67 Undang-undang Nomor 10} Tahun 2016
(1) Kampanye sebagaimana dimaksud dalam Pasal 65 ayat (1) dilaksanakan 3 (tiga) hari setelah penetapan calon peserta Pemilihan sampai dengan dimulainya masa tenang.

(2) Masa tenang sebagaimana dimaksud pada ayat (1) berlangsung selama 3 (tiga) hari sebelum hari pemungutan suara.

\section{Pasal 69 Undang-undang Nomor 10 Tahun 2016}

Dalam Kampanye dilarang:

a. Mempersoalkan dasar negara Pancasila dan Pembukaan Undang-Undang Dasar Negara Republik Indonesia Tahun 1945;

b. Menghina seseorang, agama, suku, ras, golongan, Calon Gubernur, Calon Bupati, Calon Walikota, dan/atau Partai Politik;

c. Melakukan Kampanye berupa menghasut, memfitnah, mengadu domba Partai Politik, perseorangan, dan/atau kelompok masyarakat;

d. Menggunakan kekerasan, ancaman kekerasan atau menganjurkan penggunaan kekerasan kepada perseorangan, kelompok masyarakat dan/atau Partai Politik;

e. Mengganggu keamanan, ketenteraman, dan ketertiban umum;

f. Mengancam dan menganjurkan penggunaan kekerasan untuk mengambil alih kekuasaan dari pemerintahan yang sah;

g. Merusak dan/atau menghilangkan alat peraga Kampanye;

h. Menggunakan fasilitas dan anggaran Pemerintah dan Pemerintah Daerah;

i. Menggunakan tempat ibadah dan tempat pendidikan;

j. Melakukan pawai yang dilakukan dengan berjalan kaki dan/atau dengan kendaraan di jalan raya; dan/atau

k. Melakukan kegiatan Kampanye di luar jadwal yang telah ditetapkan oleh KPU Provinsi dan KPU Kabupaten/Kota. 
Pasal 70 Undang-undang Nomor 10 Tahun 2016 :

(1) Dalam Kampanye, calon dilarang melibatkan:

a. Pejabat badan usaha milik negara/badan usaha milik daerah;

b. Aparatur sipil Negara, anggota Kepolisian Negara Republik Indonesia, dan anggota Tentara Nasional Indonesia; dan

c. Kepala Desa atau sebutan lain/Lurah dan perangkat Desa atau sebutan lain/perangkat Kelurahan.

(2) Gubernur, Bupati, Walikota, dan pejabat negara lainnya dapat ikut dalam Kampanye dengan mengajukan izin cuti Kampanye sesuai dengan ketentuan peraturan perundang-undangan.

(3) Pejabat negara sebagaimana dimaksud pada ayat (2) yang menjadi Calon Gubernur, Calon Bupati, Calon Walikota dalam melaksanakan Kampanye tidak menggunakan fasilitas yang terkait dengan jabatannya.

\section{Pasal 72 Undang-undang Nomor 10 Tahun 2016:}

(1) Pelanggaran atas ketentuan larangan sebagaimana dimaksud dalam Pasal 69 huruf a sampai dengan huruf $h$ merupakan tindak pidana dan dikenai sanksi sesuai dengan ketentuan peraturan perundang-undangan.

(2) Pelanggaran atas ketentuan larangan sebagaimana dimaksud dalam Pasal 69 huruf i dan huruf j, dikenai sanksi:

a. Peringatan tertulis walaupun belum menimbulkan gangguan; dan/atau

b. Penghentian kegiatan Kampanye di tempat terjadinya pelanggaran atau di seluruh daerah Pemilihan setempat jika terjadi gangguan terhadap keamanan yang berpotensi menyebar ke daerah lain.

(3) Ketentuan lebih lanjut mengenai tata cara pengenaan sanksi terhadap pelanggaran larangan sebagaimana dimaksud pada ayat (2) diatur dengan Peraturan KPU.

Pasal 73 Undang-undang Nomor 10 Tahun 2016

(1) Calon dan/atau tim Kampanye dilarang menjanjikan dan/atau memberikan uang atau materi lainnya untuk memengaruhi Pemilih.

(2) Calon yang terbukti melakukan pelanggaran sebagaimana dimaksud pada ayat (1) berdasarkan putusan pengadilan yang telah mempunyai kekuatan hukum tetap dikenai sanksi pembatalan sebagai calon oleh KPU Provinsi dan KPU Kabupaten/Kota dan dikenai sanksi pidana sesuai dengan peraturan perundang-undangan.

(3) Tim Kampanye yang terbukti melakukan pelanggaran sebagaimana dimaksud pada ayat (1) berdasarkan putusan pengadilan yang telah mempunyai kekuatan hukum tetap dikenai sanksi pidana sesuai dengan ketentuan peraturan perundang-undangan.

Jadi, berdasarkan pasal-pasal yang mengatur tentang hak dan kewajiban calon kepala daerah terpilih dapat ditarik kesimpulan, bahwa hak calon kepala daerah yang telah ditetapkan adalah melakukan kampanye guna menyampaikan visi, misi dan tujuan sebagai calon kepala daerah untuk meraih simpati dan dukungan dari warga masyarakat pemilih.

Implikasi Hukum Pasangan Calon Kepala Daerah Terpilih yang Berstatus Tersangka, Terdakwah dan Terpidana

Implikasi hukum terhadap pasangan calon kepala daerah terpilih yang berstatus tersangka, terdakwa, dan 
terpidana belum diatur secara jelas dalam peraturan perundang-undangan. Jika merujuk pada UU No. 32 Tahun 2004 tentang Pemerintahan Daerah, kemudian diubah dengan UU No. 12 Tahun 2008 dan diganti dengan UU No. 23 Tahun 2014 tentang Pemerintahan Daerah (terbaru) tidak ada ketentuan yang mengatur jika calon kepala daerah terpilih ditetapkan menjadi tersangka, terdakwa dan terpidana. Bagitu juga dalam UU No. 1 Tahun 2015 tentang Penetapan Peraturan Pemerintah Pengganti UU Nomor 1 Tahun 2014 tentang Pemilihan Gubernur, Bupati, Dan Walikota sebagaimana diubah yang kedua dengan UU No. 10 Tahun 2016. Kesemuanya itu hanya mengatur mengenai implikasi hukum apabila kepala daerah kemudian berstatus tersangka, terdakwa, dan terpidana.

Pasal 58 huruf F UU No. 12 Tahun 2008 hanya mengatur tentang syarat bahwa calon kepala daerah tidak pernah dihukum penjara karena melakukan tindak pidana yang ancaman hukumannya lebih dari 5 (lima) tahun. Mahkamah Konstitusi (MK) kemudian memberikan penafsiran, pasal tersebut tidak berlaku bagi mereka yang melakukan tindak pidana politik dan perkara kealpaan ringan. Kemudian Pasal 97 ayat (1) PP No. 49 Tahun 2008, yang membuat kepala daerah terpilih tidak dilantik adalah jika ia berhalangan tetap. Jika calon kepala daerah terpilih berhalangan tetap, calon wakil kepala daerah terpilih dilantik menjadi kepala daerah. Akan tetapi tidak dijelaskan lebih lanjut apa yang dimaksud dengan "berhalangan tetap". Bagi calon kepala daerah terpilih yang menang dalam Pilkada dapat dilakukan pelantikan karena status sebagai tersangka dianggap bukan "halangan tetap".

Ditetapkannya calon kepala daerah terpilih kemudian menjadi tersangka selama belum ada putusan pengadilan yang menyatakan ia terbukti bersalah, tidak serta merta membuat statusnya sebagai calon kepala daerah terpilih dicabut. Tersangka, tetap dapat menjadi calon kepala daerah terpilih karena status tersangka adalah status "berhalangan sementara" dan belum dijatuhi putusan/ vonis pengadilan/ hakim yang memiliki kekuatan hukum tetap. Dalam persyaratan calon kepala daerah yang diatur dalam pasal 7 UU No. 10 Tahun 2016 tidak ada aturan yang menyebutkan bahwa calon kepala daerah tidak boleh berstatus sebagai tersangka, tetapi yang dipersyaratkan adalah calon kepala daerah tidak pernah sebagai terpidana atau jika menjadi mantan terpidana harus secara terbuka dan jujur mengemukakan kepada publik bahwa yang bersangkutan adalah mantan terpidana. Sehingga calon kepala daerah terpilih yang berstatus sebagai tersangka masih sah sebagai calon kepala daerah terpilih.

Berbeda halnya dengan calon kepala daerah terpilih yang berstatus terdakwa maka tetap dapat menjadi calon kepala daerah terpilih jika tuntutan pidana yang diberikan kepadanya tidak lebih dari 5 tahun hukuman penjara dan karena belum dijatuhi putusan/ vonis pengadilan/ hakim. Dalam pasal 124 PP No. 6 Tahun 2005 mengatur bahwa Kepala daerah dapat diberhentikan sementara jika dinyatakan melakukan tindak pidana kejahatan yang diancam dengan pidana penjara paling singkat 5 (lima) tahun atau lebih berdasarkan putusan pengadilan.

Pasal 163 ayat (6), (7) dan (8) Undang-undang Nomor 10 Tahun 2016 menegaskan sebagai berikut :

(6) Dalam hal calon Gubernur dan/atau Calon Wakil Gubernur terpilih ditetapkan menjadi tersangka pada saat pelantikan, yang bersangkutan tetap dilantik menjadi Gubernur dan/atau Wakil Gubernur.

(7) Dalam hal calon Gubernur dan/atau Calon Wakil Gubernur terpilih ditetapkan menjadi terdakwa pada saat pelantikan, yang bersangkutan tetap dilantik menjadi Gubernur 
dan/atau Wakil Gubernur dan saat itu juga diberhentikan sementara sebagai Gubernur dan/atau Wakil Gubernur

(8) Dalam hal calon Gubernur dan/atau Calon Wakil Gubernur terpilih ditetapkan menjadi terpidana berdasarkan putusan pengadilan yang telah memperoleh kekuatan hukum tetap pada saat pelantikan, yang bersangkutan tetap dilantik menjadi Gubernur dan/atau Wakil Gubernur dan saat itu juga diberhentikan sebagai Gubernur dan/atau Wakil Gubernur.

Ketentuan tersebut berlaku bagi calon kepala daerah provinsi, sedangkan calon kepala daerah kabupaten/kota diatur dalam Pasal 164 ayat (6), (7), dan 8 Undang-undang Nomor 10 Tahun 2016, sebagai berikut:

(6) Dalam hal calon Bupati/Walikota dan/atau calon Wakil Bupati/Wakil Walikota terpilih ditetapkan menjadi tersangka pada saat pelantikan, yang bersangkutan tetap dilantik menjadi Bupati/Walikota dan/atau Wakil Bupati/Wakil Walikota

(7) Dalam hal calon Bupati/Walikota dan/atau calon Wakil Bupati/Wakil Walikota terpilih ditetapkan menjadi terdakwa pada saat pelantikan, yang bersangkutan tetap dilantik menjadi Bupati/Walikota dan/atau Wakil Bupati/Wakil Walikota, kemudian saat itu juga diberhentikan sementara sebagai Bupati/Walikota dan/atau Wakil Bupati/Wakil Walikota.

(8) Dalam hal calon Bupati/Walikota dan/atau calon Wakil Bupati/Wakil Walikota terpilih ditetapkan menjadi terpidana berdasarkan putusan pengadilan yang telah memperoleh kekuatan hukum tetap pada saat pelantikan, yang bersangkutan tetap dilantik menjadi Bupati/Walikota dan/atau Wakil Bupati/Wakil Walikota, kemudian saat itu juga diberhentikan sebagai
Bupati/Walikota dan/atau Wakil

Bupati/Wakil Walikota.

Bagi calon kepala daerah terpilih yang berstatus sebagai terpidana yang sudah dijatuhi putusan hakim yang berkekuatan hukum tetap maka harus dibatalkan menjadi calon kepala daerah terpilih. Pasal 124 PP No. 6 Tahum 2005 mengatur bahwa jika calon kepala daerah terpilih maupun calon kepala daerah terpilih yang menang dalam Pilkada terbukti melakukan tindak pidana kejahatan yang diancam dengan hukuman penjara paling singkat 5 (lima) tahun atau lebih berdasarkan putusan pengadilan yang telah mempunyai kekuatan hukum tetap, dapat diberhentikan (pemberhentian tetap) oleh pihak yang berwenang melakukan pemberhentian. Hal tersebut juga otomatis membuat calon kepala daerah terpilih yang berstatus terpidana tidak lagi memenuhi ketentuan calon dan pencalonan kepala daerah dalam Pilkada yaitu "tidak pernah sebagai terpidana berdasarkan putusan pengadilan yang telah memperoleh kekuatan hukum tetap atau bagi mantan terpidana telah secara terbuka dan jujur mengemukakan kepada publik bahwa yang bersangkutan mantan terpidana" sebagaimana yang tercantum dalam huruf $f$ pasal 7 Undang-undang Nomor 10 Tahun 2016.

Undang-undang Nomor 23 Tahun 2014 tentang Pemerintahan Daerah (terbaru), dalam pasal 76 memuat hal-hal yang dilarang untuk dilakukan seorang kepala daerah dan wakil kepala daerah. Apabila kepala daerah dan wakil kepala daerah melakukan hal-hal tersebut, maka kepala daerah dan wakil kepala daerah dapat diberhentikan dari jabatannya, hal ini diatur di pasal 78. UU ini juga hanya mengatur tentang larangan bagi kepala daerah dan wakil kepala daerah serta alasan yang dapat membuat kepala daerah atau wakil kepala daerah dapat diberhentikan dari masa jabatannya. Tidak mengatur implikasi hukum calon kepala daerah terpilih yang berstatus 
tersangka, terdakwa, dan terpidana.

\section{P E N U T U P}

Dalam pencalonan kepala daerah terdapat berbagai macam ketentuan yang telah diatur dalam Undang-undang dan Peraturan Pemerintah. Ketentuan calon dan pencalonan kepala darah dan wakil kepala daerah berlaku untuk calon dan pencalonan Gubernur, Bupati dan Walikota beserta wakil-wakilnya. Ketentuan calon kepala daerah dalam pasal 7 Undang-undang Nomor 10 Tahun 2016 wajib dipenuhi sebelum mencalonkan diri menjadi calon kepala daerah. Sedangkan, ketentuan pencalonan kepala daerah harus dipenuhi saat ingin mencalonkan diri menjadi calon kepala daerah.

Dalam pencalonan kepala daerah terdapat prosedur dan syarat pencalonan yang harus dipenuhi agar dapat ditetapkan menjadi calon kepala daerah. Calon kepala daerah yang telah ditetapkan memiliki akibat hukum baik bagi diri sendiri sebagai calon kepala daerah yang telah ditetapkan maupun bagi partai atau gabungan partai pengusung. Calon kepala daerah yang telah ditetapkan memiliki hak dan kewajiban untuk melakukan kampanye dan tidak melanggar peraturan kampanye yang telah ditetapkan. Semua ketentuan tersebut diatur dalam pasal 63-73 Undang-undang Nomor 1 Tahun 2015 jo. Undang-undang Nomor 8 Tahun 2015 jo. Undang-undang Nomor 10 Tahun 2016.

Implikasi hukum terhadap calon kepala daerah terpilih yang berstatus tersangka, terdakwa, dan terpidana belum diatur secara detail oleh Undang-undang maupun Peraturan Pemerintah (PP), tetapi ada beberapa ketentuan terkait hal tersebut yang diatur di dalam Undang-undang Nomor 1 Tahun 2015 jo. Undang-undang Nomor 8 Tahun 2015 jo. Undang-undang Nomor 10 Tahun 2016, Undang-undang Nomor 32 Tahun 2004 yang kemudian dilakukan perubahan kedua dengan
Undang-undang Nomor 12 Tahun 2008 dan diganti dengan Undang-undang Nomor 23 Tahun 2014, PP No. 49 Tahun 2008, dan PP No. 6 Tahun 2005.

Dasar hukum pengaturan implikasi hukum calon kepala daerah terpilih yang berstatus tersangka, terdakwa, dan terpidana belum secara detail diatur dalam UU Pilkada. UU Pilkada lebih banyak mengatur tentang status tersangka, terdakwa, dan terpidana yang disandang oleh kepala daerah yang sudah dilantik dan menjabat sebagi kepala daerah. Oleh karena itu, agar calon kepala daerah terpilih yang berstatus sebagai tersangka, terdakwa, dan terpidana tidak menjadi masalah yang rumit dikemudian hari karena tidak ada dasar hukum yang mengatur hal itu secara detail sehingga diperlukan aturan hukum yang mengatur secara detail mengenai hal tersebut dalam UU Pemda/Pilkada.

\section{DAFTAR PUSTAKA}

Puspen Kemendagri. 2015. Jadi Tersangka, Pecalonan Kepala Daerah Tetap Sah, Ini Kajiannya, (http://www.kemendagri.go.id/n ews/2015/11/17/jadi-tersangkapecalonan-kepala-daerah-tetapsah-ini-kajiannya), diakses pada 2 Desember 2016.

Peraturan Pemerintah Nomor 49 Tahun 2008 Tentang Pemberhentian, dan Pengangkatan Pejabat Kepala Daerah

Peraturan Pemerintah Nomor 6 Tahun 2005 Tentang Pemilihan, Pengesahan, Pengangkatan, dan Pemberhentian Kepala Daerah dan Wakil Kepala Daerah

Undang-Undang Nomor 1 Tahun 2015 Tentang Penetapan Peraturan Pemerintah Pengganti UU Nomor 1 Tahun 2014 Tentang Pemilihan Gubernur, Bupati, 


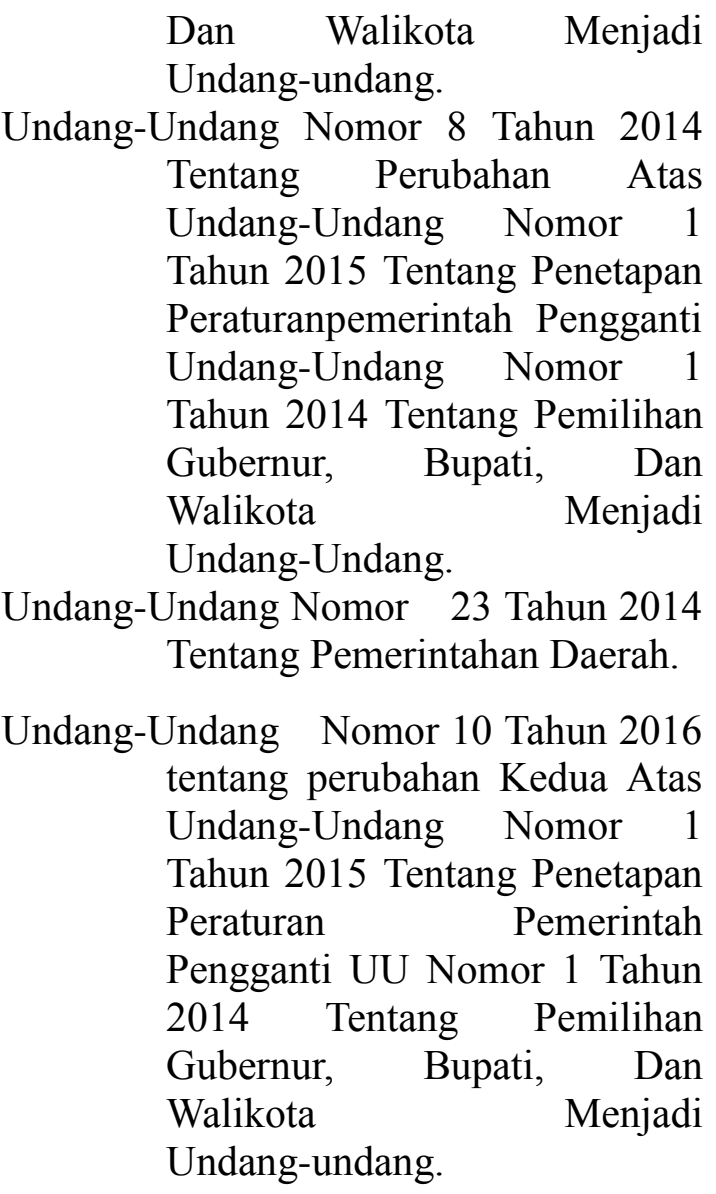

